\title{
Article
}

\section{China's Efforts in Marine Biodiversity Conservation: Recent Developments in Policy and Institutional Reform}

\author{
Wang, Jiayi and Zou, Keyuan \\ Available at http://clok.uclan.ac.uk/33513/ \\ Wang, Jiayi and Zou, Keyuan ORCID: 0000-0002-2868-4948 (2020) China's \\ Efforts in Marine Biodiversity Conservation: Recent Developments in Policy \\ and Institutional Reform. The International Journal of Marine and Coastal Law, \\ 35 (2). pp. 409-423. ISSN 0927-3522
}

It is advisable to refer to the publisher's version if you intend to cite from the work. http://dx.doi.org/10.1163/15718085-BJA10008

For more information about UCLan's research in this area go to http://www.uclan.ac.uk/researchgroups/ and search for < name of research Group>.

For information about Research generally at UCLan please go to http://www.uclan.ac.uk/research/

All outputs in CLoK are protected by Intellectual Property Rights law, including Copyright law. Copyright, IPR and Moral Rights for the works on this site are retained by the individual authors and/or other copyright owners. Terms and conditions for use of this material are defined in the policies page.

\section{CLoK}

Central Lancashire online Knowledge www.clok.uclan.ac.uk

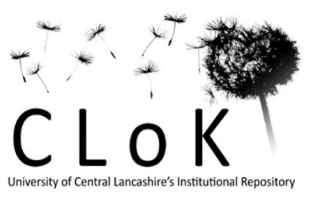




\section{The International Journal of Marine and Coastal Law \\ China's Efforts in Marine Biodiversity Conservation: Recent Developments in in Policy and Institutional Reform \\ --Manuscript Draft--}

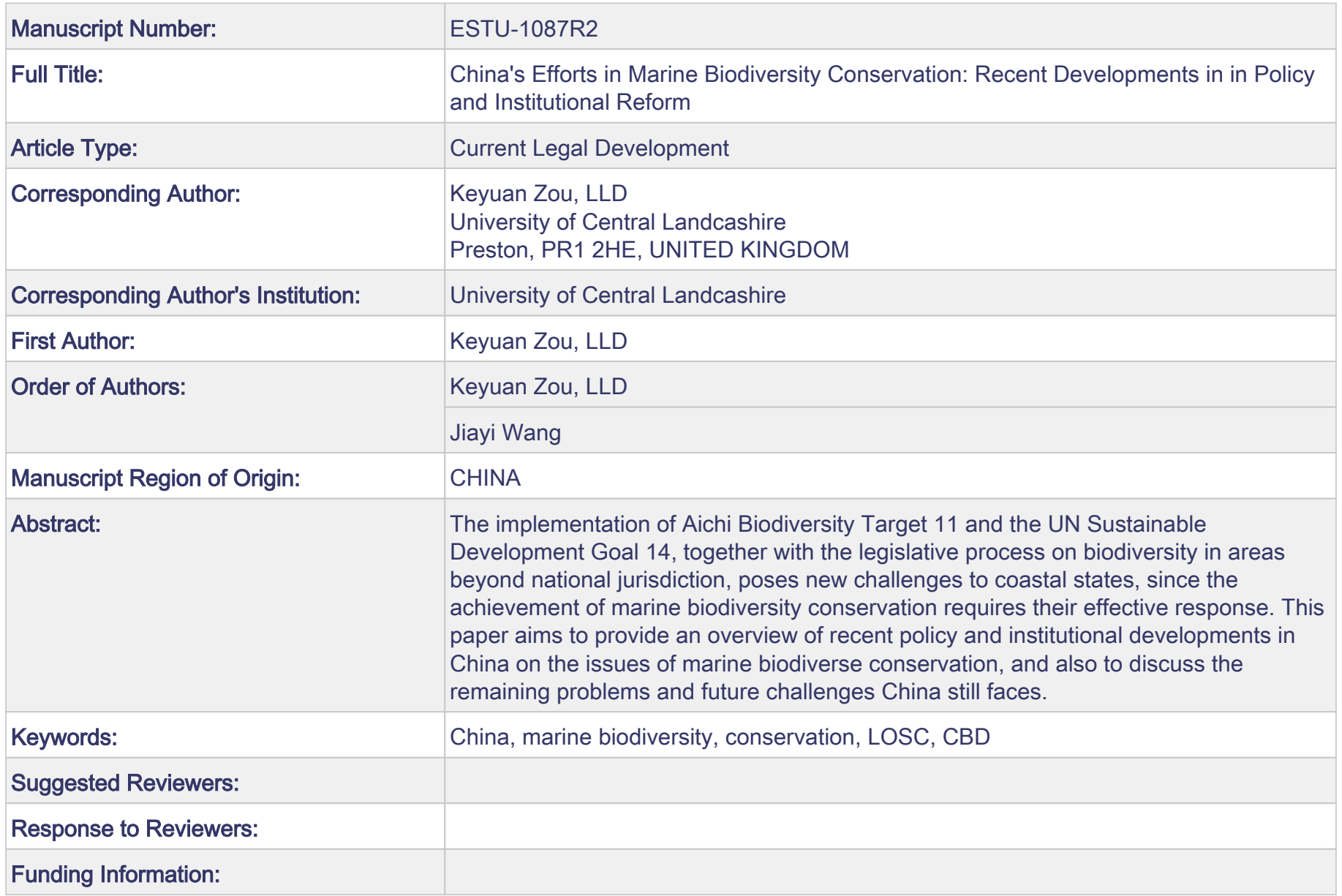




\section{Current Legal Developments}

\section{China}

\section{China's Efforts in Marine Biodiversity Conservation: Recent Developments in Policy and Institutional Reform}

\section{Introduction ${ }^{1}$}

Marine biodiversity plays a vital role in maintaining a healthy marine ecosystem. However, an investigation by the WWF shows that there has been a substantial and irreversible loss in marine diversity: marine populations have declined by $49 \%$ between 1970 and $2012 .{ }^{2} 737$ marine species are threatened to extinction. ${ }^{3}$ In recent years, the international community has taken steps to conserve marine biodiversity. In 2010, States parties to the Convention on Biological Diversity (CBD) adopted a revised Strategic Plan for Biodiversity 2011-2020, ${ }^{4}$ which establishes five strategic goals which are further articulated through 20 Aichi Biodiversity Targets. ${ }^{5}$ Target 11 provides that 'by 2020 , at least 10 percent of coastal and marine areas, especially areas of particular importance for biodiversity and ecosystem services are conserved. ${ }^{6}$ This target was later reaffirmed in the 2030 Agenda for Sustainable Development

1 This paper is part of a research project funded by China's National Social Sciences Foundation (18VHQ002).

2 World Wildlife Fund, 'Living Blue Planet Report: Species, habitats and human well-being' available at https://c402277.ssl.cf1.rackcdn.com/publications/817/files/original/Living_Blue_Planet_Report_2015_Final_LR.p df?1442242821; accessed 25 August 2019.

${ }^{3}$ International Union for Conservation of Nature's (IUCN) Red List of Threatened Species, 'Species ExtinctionThe Facts' available at https://cmsdata.iucn.org/downloads/species_extinction_05_2007.pdf; accessed 25 August 2019.

${ }^{4}$ Strategic Plan for Biodiversity 2011-2020 and the Aichi Biodiversity Targets, adopted by the Conference of the Parties to the CBD at its Tenth Meeting in 2010. Available at https://www.cbd.int/doc/strategic-plan/2011 2020/Aichi-Targets-EN.pdf; . accessed 25 August 2019.

5 The goals and targets comprise both aspirations for achievement at the global level, and a flexible framework for the establishment of national or regional targets.

${ }^{6}$ Target 11 is under the Strategic Goal C: to improve the status of biodiversity by safeguarding ecosystems, species and genetic diversity, which provides that by 2020 , at least 17 per cent of terrestrial and inland water, and 10 per cent of coastal and marine areas, especially areas of particular importance for biodiversity and ecosystem services, 
in $2015 .^{7}$

Meeting the Aichi Biodiversity Target 11 and the UN Sustainable Development Goals pose new challenges to coastal states because the achievement of marine biodiversity conservation targets requires their effective policy and regulatory measures within domestic law. This paper provides an overview of recent policy and institutional developments in China in respect of marine biodiverse conservation and discusses both present and future challenges facing China her efforts to meet her international commitments.

\section{Policy Developments}

China has not formulated a comprehensive policy on marine biodiversity. However, the National Biodiversity Strategy and Action Plan (NBSAP),${ }^{8}$ the $13^{\text {th }}$ National Five-year Plan for Marine Economic Development (2016-2020), ${ }^{9}$ the National Plan for Marine Ecological and Environmental Protection (2017-2020) ${ }^{10}$ and the National Marine Functional Zoning plan (2011-2020) ${ }^{11}$ contain relevant policy content on marine biodiversity. In combination, the four

are conserved through effectively and equitably managed, ecologically representative and well connected systems of protected areas and other effective area-based conservation measures, and integrated into the wider landscapes and seascapes.

7 Transforming our world: the 2030 Agenda for Sustainable Development, UN Doc. A/RES/ 70/1. Available at http://www.un.org/ga/search/view doc.asp?symbol=A/RES/70/1\&Lang=E; accessed 26 August 2019. Goal 14, sub-target 14.5 reaffirms the Aichi Target 11, providing by 2020 to conserve at least 10 per cent of coastal and marine areas, consistent with national and international law and based on the best available scientific information. Specific targets were set out in SDG 14, including prevention of marine pollution, expansion of marine protected areas, regulation of overfishing, increase of scientific knowledge as well as intensification of research capability and technology transfer, that will have a direct contribution to the conservation of marine biodiversity.

8 China's first Biodiversity Protection Action Plan was officially released on 13 June 1994. Due to the lack of national strategy content and the insufficient coverage of important provisions of CBD, an updated National Biodiversity Strategy and Action Plan (2011-2030) was issued in 2010, the full text is available at www.cecachina.org/news_view.asp?id=1143; accessed 26 August 2019.

9 The $13^{\text {th }}$ National Five-year Plan for Marine Economic Development (in Chinese), May 2017, available at www.askci.com/news/finance/20170519/11384298471.shtml; accessed 26 August 2019.

10 The State Oceanic Administration formulated the National Plan for Marine Ecological and Environmental Protection shortly after the closing of the 19th National Congress of the Communist Party, based on its responsibility of organizing and carrying out marine ecological and environmental protection, and the National Plan for Marine Ecological and Environmental Protection is positioned as a guiding plan for departments in marine affairs.

11 The National Marine Functional Zoning (2011-2020) (in Chinese), August 2015, available at www.gov.cn/zhengce/content/2015-08/20/content_10107.htm; accessed 26 August 2019. 
instrument provide a general policy framework for marine biodiversity conservation.

In order to give effect to the Aichi Targets, China updated its national biodiversity strategy in 2010. Updating the NBSAP was a participatory process, engaging a wide range of stakeholders. ${ }^{12}$ The NSBAP establishes four basic principles for biodiversity conservation: conservation first, sustainable use, public participation, and benefit sharing. It identifies the Yellow and Bohai Seas Protected Region, the East China Sea and Taiwan Strait Protected Region, the South China Sea Protected Region as the priority areas for marine and coastal biodiversity conservation._-In its short-term strategy, ${ }^{13}$ the Chinese government is required to make sure 90 percent of national key protected species and typical ecosystems would be at a favorable conservation status by $2015 .{ }^{14}$ In its long-term strategy, by 2020 , the trends of ecological and environmental deterioration in coastal and near-shore areas will be fundamentally reversed and the decline tendency of marine biodiversity will be curbed. ${ }^{15}$

At the 19th National Congress of the Communist Party of China (CPC) on 18 October 2017, President Xi Jinping confirmed that building an ecological civilization to ensure the harmony between man and nature was one of the 14 points of the basic strategy of Chinese socialism. $\mathrm{He}$ advanced the requirement to speed up the reform of governance systems for developing ecological civilization. ${ }^{16}$ The specific tasks required to achieve ecological progress include: promoting green development, solving prominent environmental problems, intensifying ecological systems protection, and reforming the environmental regulation system. ${ }^{17}$ The

12 The updating process of NBSAP took three years and consulted more than 20 central government departments and 31 provincial governments, and it is also an outcome of the joint efforts of China's Coordinating Group for Implementation of the Convention of Biological Diversity and the Inter-ministerial Joint Conference on Conservation of Biological Resources. See Ministry of Environmental Protection of the People's Republic of China, China's Fifth National Report of the Implementation of the Convention on Biodiversity (China Environment Press, Beijing, 2014) 176.

13 The NBSAP established three major goals for three periods of time: the short-term Goal: by 2015, effective control of the declining trend of biodiversity in key areas; the mid-term Goal: by 2020 , general control of biodiversity decline and loss; and the long-term Goal: by 2030, biodiversity in China will have been effectively protected.

14 The National Biodiversity Strategy and Action Plan (2011-2030), Short-term Strategy, paragraph 1.

15 The National Biodiversity Strategy and Action Plan (2011-2030), Long-term Strategy, paragraph 3.

$16 \mathrm{Xi}$ Jinping's Speech at the 19th National Congress of the Communist Party of China, available at www.xinhuanet.com/english/special/2017-11/03/c_136725942.htm; accessed 26 August 2019.

17 Ibid. 
concept of ecological civilization was first proposed at the 17th National Congress of CPC in 2007. The objective of giving prominence to ecological civilization was then incorporated in the Constitution of the Communist Party as a guide of action in the 18th National Congress of the CPC. ${ }^{18}$ In order to turn the slogan into reality, 'building an ecological civilization' was endorsed as a major framework for environmental laws and policies in the Third Plenary Session of 18th Central Committee of CPC. ${ }^{19}$ The Fourth Plenary Session of this committee further stressed the goal of 'advancing the law based governance', through the rule of law. This provided a powerful driver for ecological progress. ${ }^{20}$

The government is required to speed up the establishment of a legal system that effectively promotes green, circular and low-carbon development. It is also required to strengthen legislation on ecological compensation and pollution prevention, as well as protection of marine environment. ${ }^{21}$ Since it was introduced, ecological civilization has become a fundamental guidance for the development of new and stricter environmental policies and laws. Thus, the Law on Marine Environment Protection of People's Republic of China (LEMP) was amended in $2017^{22}$ to define marine ecological red lines (MERL) ${ }^{23}$ and provide for marine ecological compensation systems as the fundamental systems of marine environmental protection. ${ }^{24}$ The concept of MERL is an approach related to marine spatial planning; it refers to the geographical boundary line of the areas with special important ecological functions that should have

18 'Building of an ecological civilization' was incorporated in the Constitution of the Communist Party in the 18th Nation Congress of the CPC in 2012.

${ }^{19}$ See Communiqué of the Third Session of the 18th Central Committee of the Communist Party of China.

20 Communiqué of the Fourth Plenary Session of the 18th Central Committee of the Communist Party of China, page 2, para.5. Available at book.theorychina.org/upload/ae0b0b63-7c4a-4f50-b978-3ddceafabb89/; accessed 26 August 2019.

${ }^{21}$ Decision of the CPC Central Committee on Major Issues Concerning Comprehensively Promoting the Rule of Law, November 2014, available at www.wangcanggsl.gov.cn/article_view.aspx?aid=190; accessed 26 August 2019. 22 The LMEP was amended for the third time and came into effect on 5 November 2017. The full text is available at https://www.pkulaw.com/en_law/174b2b5043ca235dbdfb.html; accessed 26 August 2019.

${ }^{23}$ The amended LMEP adds a new clause into the general provisions that 'the State sets ecological protection red lines in key marine ecological functional zones, eco-sensitive areas and fragile zones, and strictly implements protection' (Art.3). The essential objective of marine ecological red line is to identify the important marine ecological functional area, marine ecological fragile area and marine ecological sensitive area, then to further subdivide them into prohibited and restricted development zones according to ecological characteristics and management objectives. ${ }^{24}$ Article 24 of the amended LMEP provides that 'The state shall establish and improve a compensation system for marine ecological protection.' 
mandatory strict protection. ${ }^{25}$ When the MERL is delineated, coastal governments should fix control indicators according to the ecological environmental and socio-economic situation. ${ }^{26}$ In the context of management planning, the MERL provides a bottom line for the marine environmental management. The marine ecological compensation mechanism is an important step taken by the Chinese government to protect the marine environment and to coordinate the ecological interests of various stakeholders. It includes two types of compensation: marine protective compensation, which refers to the government's expenditure on the restoration of the marine ecosystem that is damaged by cumulative adverse effects of historical development activities and compensation for the ecological protectors from beneficiaries, ${ }^{27}$ and marine ecological damage compensation, which ensures the maritime administration for seeking compensation on behalf of the state against the responsible person who caused damage to the marine ecology, marine resources and marine protected areas. ${ }^{28}$ The compensation includes

25 Opinions on Defining and Protecting Ecological Redlines, issued by the Central Committee and the State Council, February 2017, available at www.gov.cn/zhengce/2017-02/07/content_5166291.htm; accessed 26 August 2019.

26 Take the MERL of Bohai Sea as an example. The control indicators include that 'the retention rate of Bohai shoreline is not less than $40 \%$; the proportion area of the MERL zones in the Bohai Sea area under Shandong province is not less than $40 \%$; by 2020 , in the MERL zones, $100 \%$ of the pollutants discharged from direct drain outlets must meet the acceptable standard, and the total amount of land-based pollutants entering into the sea must be reduced by $10-15 \%$.'

27 YH Jiang, JW Zhang, KL Chen, XZ Xue, and M Adi Uchenna, 'Moving towards a systematic marine ecocompensation mechanism in China: policy, practice and strategy (2019)169(1) Ocean \& Coastal Management 1019, at p.11. The measures related to marine protective compensation include financial subsidies for important ecological areas and subsidies to local affected individuals. It should be noted due to the establishment of marine ecological red line in the prohibited and restricted areas, economic development is constrained due to ecological protection. China has introduced a financial transfer payment mechanism to ensure the protected regions are properly compensated by the beneficiary regions.

${ }^{28}$ LMEP, Article 89. According to Article 9 of the Constitution of PRC and Article 46 of the Real Right Law, waters and sea areas shall be in the ownership of the state; thus, the state has rights to seek compensation for damages. It should be noted that in the judicial practice of China, the scope of marine ecological damages includes loss of marine environmental capacity, loss of marine nature resources and loss of ecological service. Due to the division of state government functions, the responsible person might be sued by different departments on behalf of the state, this was reflected in the "Tasman sea" oil spill case. In this case, the Infinite Shipping Co. Ltd. and the London steamboat ship owners association were sued by Tianjin Maritime Administration for the loss of marine environmental capacity and marine ecological service and by Tianjin fishery management administration for the compensation for loss of fishery. See F Tang and XL Rong, 'Compensation for Maritime Ecological Damages in China Judicial Practice' (2016)12(1) Cross Cultural Communication 40-43.
Commented [RAB1]: This requires clarification as there appear to be three named types of compensation, but only two are indicated at the start of the sentence. 
the cost for preventive measures, restoration expenses, loss during restoration and investigation expenses. ${ }^{29}$

A second important piece of legislation is the Environmental Protection Tax Law (EPTL). ${ }^{30}$ This came into effect on 1 January 2018, introducing environmental protection taxes on both land and sea discharges. At the same time, China started to implement a new ban on household plastic imports. $^{\beta 1}$

The concept of ecological civilization was also incorporated into the $13^{\text {th }}$ Five-year National Plan for Marine Economic Development (2016-2020). ${ }^{32}$ This plan calls for an expansion of the blue economy, promotion of the scientific utilization of marine resources and protection of the marine environment. It places greater emphasis on marine ecological civilization. The marine ecological progress, adhering to the principle of giving priority to conservation, protection and natural recovery, involves four major parts and a series of specific measures (see Table 1). The updated plan attached equal importance to development and protection to strengthen the conservation and sustainable use of marine resources and control of sources of marine environmental pollution. To aid implementation of the plan, safeguard measures to strengthen macro guidance and policy adjustment, improve related systems and implementation mechanism as well as to conduct monitoring and evaluation have been highlighted. . $^{3} \mid$

${ }^{29}$ Supreme People's Court on Handling Cases concerning Compensation Disputes over Marine Natural Resources and Environmental Damage, Art.2.

30 The EPTL was passed at the 25th Session of the 12th National People's Congress in December 2016.

31 The Implementation Plan for the Reform of the Import Management System of Solid Waste was adopted at the 34th Meeting of the Central Leading Group for Deepening Overall Reform. Under this, solid wastes that cause great environmental damage would be forbidden from import by the end of 2017 , and the imported solid wastes that can be replaced by domestic resources should be phased out by the end of 2019 .

${ }^{32}$ It was jointly issued by the National Development and Reform Commission and the State Oceanic Administration in 2017. Ecological progress is an important part of the China's $13^{\text {th }}$ National Five-year Plan for Marine Economic Development. In the chapter setting out the overall objectives, it is provided that 'by 2020, remarkable achievements have been made in the construction of marine ecological civilization, with the rate of natural shoreline retention is not less than $35 \%$, and $70 \%$ of coastal waters meet the water quality standard--Class I and II.'

33 The $13^{\text {th }}$ Five-year National Plan for Marine Economic Development (2016-2020), Chapter 8.
Commented [RAB2]: The name of the legislation in the footnote is not clear - it looks like the title of a body. Is the designation law missing?

Commented [RAB3]: Please review the last sentence as this is unclear - what is replacing imported waste and why?

Commented [RAB4]: Suggest replace with: Marine ecological civilization encompasses the principle of giving priority to conservation, protection and natural recovery, and involves...

Commented [RAB5]: Four parts are indicated, but the table lists five objectives.

Commented [RAB6]: In the footnote you refer to the Five-year National Plan for Marine Economic Development. Yet in the previous footnote it is: $3^{\text {th }}$ National Five-year Plan for Marine Economic Development. Please be consistent with the names. 
Table 1: The Contents of Marine Ecological Civilization

\begin{tabular}{|c|c|}
\hline Objectives & Measures \\
\hline $\begin{array}{l}\text { Marine ecological protection and } \\
\text { restoration }\end{array}$ & $\begin{array}{l}\text { - To strengthen marine ecological protection } \\
\text { - To carry out wetland and ecological reef } \\
\text { restoration projects }\end{array}$ \\
\hline $\begin{array}{l}\text { Integrated management of marine } \\
\text { environment }\end{array}$ & $\begin{array}{l}\text { - To implement the marine pollutant discharge } \\
\text { licensing system } \\
\text { - To establish the system of public disclosure of } \\
\text { marine environmental information- } \\
\text { - To strengthen data sharing of pollution source } \\
\text { monitoring }\end{array}$ \\
\hline $\begin{array}{l}\text { Intensive and economical use of } \\
\text { marine resources }\end{array}$ & $\begin{array}{l}\text { - To implement restrictive index management for } \\
\text { reclamation area }\end{array}$ \\
\hline $\begin{array}{l}\text { Developing low-carbon marine } \\
\text { industry }\end{array}$ & $\begin{array}{l}\text { - To speed up marine industry energy consumption } \\
\text { adjustment } \\
\text { - To encourage low-energy, low-emission marine } \\
\text { services }\end{array}$ \\
\hline Increasing marine disaster & - To strengthen infrastructure and risk assessment \\
\hline
\end{tabular}

34 The measures to strengthen marine ecological protection include: to establish marine ecological red line system, which refers to the geographical boundary line of the areas with special important ecological functions that should have a mandatory strict protection; to implement the coastal shelter forest system construction project; to speed up the construction of marine protected areas; to strengthen ecological protection and restoration of coastal zones; and to improve the marine ecological environment compensation system. 


$$
\text { prevention capacity }
$$$$
\text { Source: The 13th Five-year National Plan for Marine Economic Development. }
$$

To put the guiding principles into action, the State Oceanic Administration (SOA) issued the National Plan for Marine Ecological and Environmental Protection (2017-2020) in February 2018. This updated plan was based on the principle of ecological orientation, highlighting the ecosystem approach and comprehensive marine governance. ${ }^{35}$ The arrangement of tasks under the plan involves six priority areas covering the whole process of marine governance: building a pattern of green development, strengthening marine ecological protection, promoting marine environmental restoration, strengthening joint prevention and control of land and sea pollution, preventing and controlling of marine environmental risks, and to promoting marine ecological and environmental monitoring. These task arrangements are oriented towards giving priority to conservation and promote a sound marine economic structure. Great importance is attached to shifting the protection of ecosystems from the present decentralized and fragmented regime to one subject to centralized integration. To strengthen marine ecological protection, four major tasks are highlighted, including completing work on drawing MERL, developing a network of marine protected areas (MPA), conserving marine biodiversity, and protecting ecological environment of island and reefs.

Developing a network of MPAs has also been referred in the National Marine Functional Zoning policy (2011-2020) issued by the State Council in 2015. It was the first attempt of China to connect the main marine functional zones with marine conservation. The plan sets the goal that by 2020 , the total area of MPA will exceed $5 \%$ of the sea under China's national jurisdiction and of which over $11 \%$ comprises coastal marine areas. ${ }^{36}$ The expansion of the MPA coverage in China's sea areas can have significant benefits to preserve critical habitats and conserve marine biodiversity. The development of the MPA network not only matches the

${ }^{35}$ 'Director of the State Oceanic Administration elaborated the National Marine Ecological and Environmental Protection Plan (2017-2020)' available at www.soa.gov.cn/zwgk/zcjd/201802/t20180213_60387.html, accessed 26 August 2019.

36 National Marine Functional Zoning (2011-2020), chapter 2: the overall objectives, paragraph 4.
Commented [RAB7]: How did the plan work since part of the period is before it was adopted? Please clarify. 
spirit of 'ecological civilization', it also helps China to meet her commitments on the Aichi Biodiversity Target $11 .^{37}$

The current developments in Chinese marine policy and legislation show that the basic policy is shaped by the idea of ecological civilization, and suggest that the strategy is increasingly holistic and unified. It places emphasis on the connections between marine economic development and marine environment protection and reflects a more comprehensive and systematic management scheme for prior-prevention, in-process control and supervision.

After the 19th National Congress of the CPC, the policy of ecological civilization was given a more prominent profile. On 11 March 2018, the 13th National People's Congress adopted the Constitution of the PRC (2018 Amendment). Ecological civilization was written into the Constitution. ${ }^{38}$ Under this, the State Council is granted functions and powers "to build of an ecological civilization". ${ }^{39}$ With its express incorporation into the Constitution, ecological progress truly enters into the five-sphere integrated plan. ${ }^{40}$ The relevant contents of ecological civilization in the Constitution provide the fundamental legal basis for ecological progress and ensure the coordination between Party's regulation and national legislation. Basic laws and regulations can be used comprehensively and systematically implement the legal norm of ecological civilization. These developments have resulted in institutional reform ${ }^{41}$ related to marine biodiversity conservation.

37 YZ Li and DL Fluharty, 'Marine protected area networks in China: Challenges and prospects' (2017) 85 Marine Policy 8-16, at p 9.

${ }^{38}$ In the preface, it provides that 'to promote the coordinated development of material, political, spiritual, social, and ecological civilizations to build China into a great modern socialist country that is prosperous, powerful, democratic, civilized, harmonious, and beautiful and achieve the grand rejuvenation of the Chinese nation'. In the Constitution (2004 Amendment), it only refers to 'to promote the coordinated development of material civilization, political civilization and spiritual civilization'. There is no mention of social and ecological civilization.

39 Constitution (2018 Amendment), Art. 89(6).

${ }^{40}$ The five-sphere integrated plan is the overall plan for building socialism with Chinese characteristics. It refers to promoting economic, political, cultural, social, and ecological progress to achieve socialist modernization and the great renewal of the Chinese nation.

41 Prior to 2018, natural resource management of China followed a sectoral approach. The management of groundwater, seas, agricultural effluents, forests, and river basin, each fell under a different government department that resulted in the fragmentation of management. The ecological civilization emphasis on the systematic ecological environmental governance and holistic resources management. The implementation of ecological civilization is one of the key reasons for China's ministerial structure reform in 2018.

Commented [RAB8]: This does not translate well: 'to build an ecological civilization'. 


\section{Institutional Developments}

In the context of the central government's great push for ecological civilization, China's ocean and coastal management system has become focused more on the integrity of marine ecology and the functions of ecological services. Major reforms have been made to the structure of institutions. In March 2018, China announced the plan for the reforms of ministerial structure to better manage natural resources and fight pollution. Under the reform, nature reserves, scenic areas, natural heritage sites and geological parks which were under the administration of the SOA, the Ministry of Land and Resources, the Ministry of Water Resources and the Ministry of Agriculture were taken over by the newly established Ministry of Natural Resources (MNR). ${ }^{42}$

The reformed ministerial structure brought a divided governance of different natural resources, such as land, oceans, lakes, forests and wetland under one roof, and began the process of managing them as one entire ecosystem. This centralized management approach will help to eliminate duplications in spatial planning and avoid disputes about jurisdiction over marine reserves. ${ }^{43}$ For example, under the previous institutional arrangements, marine reserves were sometimes managed by two or more authorities. ${ }^{44}$ This potentially weakened the effectiveness of conservation measure since the authorities might have different conservation objectives. The new MNR will have general jurisdiction over all marine reserves and manage most activities within a single reserve. ${ }^{45}$ The division of land and sea management in marine reserves will come to an end. This significant change reflects a holistic and ecosystem-based management of marine reserves.

However, the reform also creates challenges. The MNR is mainly responsible for the management of natural resources, while the Ministry of Ecology and Environment (MEE) is charged with the management of pollution from all sources. (see Figure 1). Since the two newly

42 See the Chinese Communist Party Central Committee, Plan on Deepening Reform of Party and State Institutions, available at http://www.scopsr.gov.cn/zxdd/zdxw/201803/t20180321_305088.html, accessed 26 August 2019.

${ }^{43}$ Key environmental development activities, and ecological damage restoration activities that have an impact on the ecological environment should be under the supervision of the Ministry of Ecology and Environment.

${ }_{44}$ Marine reserves originally under the administration of the SOA mostly contain parts of coastal wetlands, which are also under the jurisdiction of the former State Forestry Administration. Therefore, there are often two or even more authorities in one marine reserve. 
established ministries now have multiple-sector responsibilities, the question arises as to how to address the marine biodiversity conservation in a united and coordinated way.

Figure 1: The Reform of Ministerial Structure on Natural Resources Management and Ecological Environmental Protection

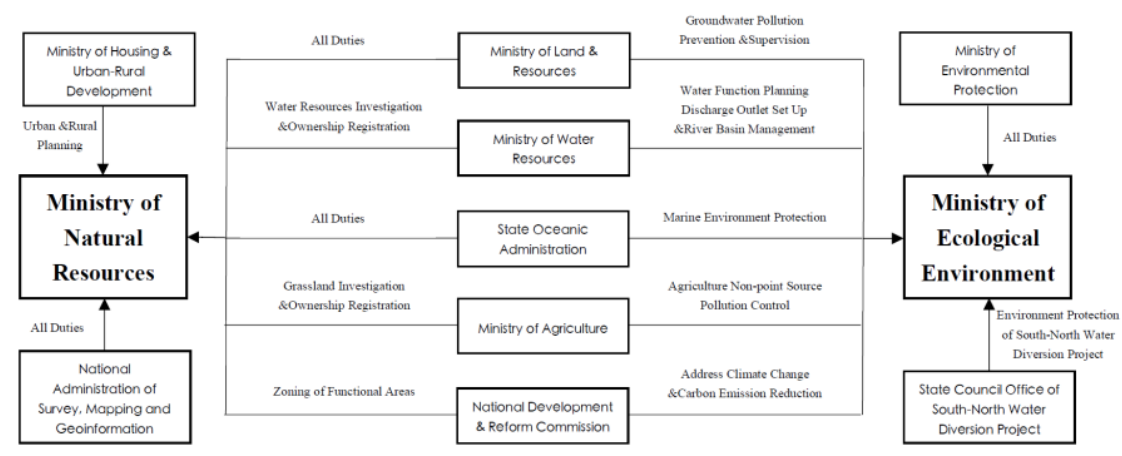

Source: Communist Party of China Central Committee, 'Plan on Deepening Reform of Party and State Institutions', March 2018.

The consolidation of relatively small ministries into mega institutions is a long-term project, as the ministries work to harmonise their mandates. The initial stage of institutional adjustment has resulted in a preliminary agglomeration of primary and secondary functions of resources conservation and environmental protection. ${ }^{46}$ The MNR and MEE have developed their organisational structure and completed staffing adjustments. The operational relationship between the two ministries has also been established (see Figure 2). The MNR is responsible for formulating policies for marine economic development, the utilization of marine resources and the conduct of marine ecological restoration, while the MEE is responsible for supervising the implementation of policies with the object of ecological protection. However, this alignment is not entirely perfect. The functions of the MNR are more extensive than those of the MEE.

${ }^{46}$ Before the new institutional reform of 2018, the main functions of resource and environmental protection should be combined with other sub-functions in the field of administrative management. For example, The Ministry of Environmental Protection undertakes the main responsibilities of environmental protection, however, some environmental protection functions are still scattered in other departments, such as marine, port, fishery, public security, transportation and other departments. 
The MNR has additional objectives of the protection of ecological environment, promoting the development of marine economy and the effective utilization of marine natural resources.

The pursuit of both economic and ecological values is to a certain extent contradictory. The supervisory function of the MEE can effectively restrict and supervise the economic function of the MNR, however, there is no clear hierarchy between the two ministries. From this perspective, how to coordinate the potential conflicts between the two ministries is a longterm challenge. On $2^{\text {nd }}$ June 2018, the State Council publicized its newly revised regulations to guide its work. ${ }^{47}$ The aim of these is to strengthen the coordination of the two ministries by adding a new regulation to enhance legislative coordination and introduce third-party assessments of important legislative issues that are the object of controversy between ministries. ${ }^{48}$ However, this is only an initial achievement, and the in-depth integration of and smooth communication between the two ministries in decision-making remains a long-term task.

Figure 2: Departments Having Competence in Marine Resources and Environment Management under MNR and MEE

${ }^{47}$ Available at http://www.gov.cn/zhengce/content/2018-07/02/content_5302908.htm, accessed 26 August 2019.

${ }^{48}$ State Council Work Rules, Art.20.
Commented [RAB9]: Please review this sentence it is circular since the MEE supervisory function can supervise 

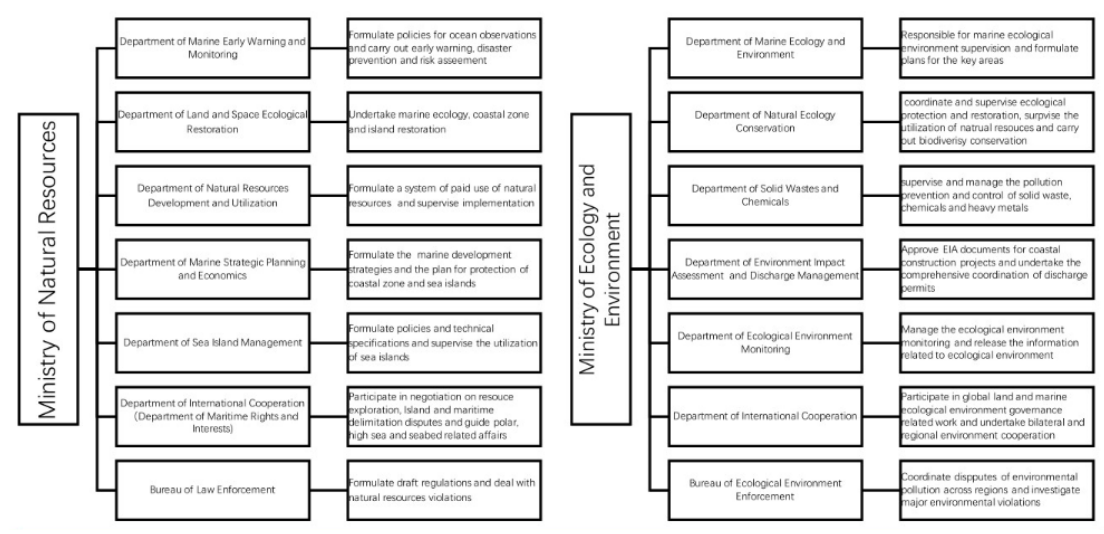

Source: Regulations on the Allocation of Functions, Internal Bodies, and Staffing of Ministry of Natural Resources; Regulations on the Allocation of Functions, Internal Bodies, and Staffing of Ministry of Ecology and Environment.

The management of the marine reserves is now the responsibility of the MNR. The challenge of addressing the inclusive and comprehensive management of land and sea and taking consideration of marine biodiversity into the management of marine reserves will be a test of the new ministry's capacity and competence. It is opined by Professor Xue Guifang, whe is a professor at Shanghai Jia Tong University, that how to address the comprehensive management of land and sea and take the consideration of marine biodiversity into the management of marine reserves will be a test of the alsotests the new institutional capacity and competence. ${ }^{49}$ He observes that It is opined that since some types of marine reserves which had been establishedwere established decade ago for decades-have accumulated some good management experience, it is unclear whether the former authorities can pass all the management experience onto a body that previously only managed reserves on land. ${ }^{50}$ Besides the issue of inter-ministerial coordination, there remains a question about how to disentangle the vertical relationship between the central government and the local authorities. The new

${ }^{49}$ Reported in C Zhang, 'How 'viper island' started a wave of coastal conservation' 2018(11) Chinadialogue Ocean. available at https://chinadialogueocean.net/4641-how-viper-island-started-a-wave-of-coastalconservation/?lang=zh-hans, accessed 26 August 2019 .

${ }^{50}$ - C Zhang, 'How 'viper island' started a wave of coastal conservation' 2018(11) Chinadialogute Ocean, available at https://chinadialogueocean.net/4641-how-viper-island-started-a-wave-of-coastal-conservation/?lang=zh-hans accessed 26 August 2019 . 
institutional structures will inevitably trigger the adjustment of the relevant local government agencies, the transition of the departments' duties and relocation of the departments' interests. This is an urgent matter and needs to be addressed by the central government. Finally, it should be recalled that China's National Plan for Marine Ecological and Environmental Protection 2017-2020 was been formulated by SOA. The continued, and the-implementation of this plan is also a problemchallenge. This is because the plan was based on the old institutional structure and will need to be reviewed to account for the Under the new situation-of-organizational restructuring and transfer authority to of the new executing agency (MNR)execution body, how to achieve the goals of marine protection set forth in the national plan will be a great challenge. This plan covers a great deal of so much ground and contain ten 10 main targets. It is expected that, it seems like-those targets will be passed on the MNR and MEE. However, ,-however, it is not yet unclear whether the plan will be continued by these ministries. Or it may be, or it will be temporarily shelved until the new organizational framework is finalized. If the plan is to be continued and achieved, Fo better achieve the aims of this plan, there needs to be a revised operational regime to ensure the actions under the plan are implemented by the MNR and MEE.

\section{Conclusion}

The-Mmarine biodiversity is a basic component of global bio-support system, and a key object the conclusion of Aichi Biodiversity Targets. Domestic Chinese and the-legislative processes reflect the increasing concern of the international community on the issue of marine biodiversity conservation. In China, there have been some positive policy, legal and institutional developments for supporting the protection of the marine biodiversity. However, the very recent institutional changes hich introducedsome new mechanisms pose various new challenges in China. This reflects perhaps the underlying need to match the complexity of complex natural systems with coherent institutional structures. -Paradoxically, the changes may slow down achieving some goals as new systems take time to be come into operation. as Tthe implementation of the new strategy on the conservation of marine biodiversity is still at the initial stage. It remains to be seen is the institutional developments are up the the challenge.

Jiayi Wang, Guanhua Law School, Zhejiang University, China 
Keyuan Zou, Member of the Editorial Board of this Journal 